\title{
Online Interactive Multimedia Oriented to HOTS through E-Learning on Physics Material about Electrical Circuit
}

\author{
Sri Wahyu Widyaningsih" ${ }^{\star}$, Irfan Yusuf ${ }^{2}$, Zuhdan Kun Prasetyo ${ }^{3}$, Edi Istiyono ${ }^{4}$ \\ 1,2Physics Education Department, Universitas Papua, Manokwari, Indonesia \\ 3,4Physics Education Department, Universitas Negeri Yogyakarta, Yogyakarta, Indonesia \\ e-mail: s.widyaningsih@unipa.ac.id, i.yusuf@unipa.ac.id, zuhdan@uny.ac.id, edi_istiyono@uny.ac.id
}

\begin{abstract}
Abstrak
This article explains the development of interactive multimedia which is designed using elearning. The development technique uses ADDIE model which consists of some stages namely Analyze, Design, Development, Implementation, and Evaluation. The trial subjects in this study were 13 students of Physics Education Department in Universitas Papua who programed basic physics courses in the even semester of 2018-2019. Interactive multimedia validity was obtained based on an assessment sheet filled by 7 validators consisting of material expert validators, media experts and practitioners. Meanwhile, the effectivity and practicality of interactive multimedia was obtained based on the students' responses after learning. The instrument used in this study was the validation sheet filled out by the validators and questionnaire about students' responses after learning. The technique used to analyze the results of the validator's assessment was $V$ Aiken while the questionnaire analysis used Rasch model. The results showed that the developed learning media were in the valid category for each aspect of the assessment, namely layout, navigation, functions, and pedagogy aspects. Moreover, students' responses towards interactive multimedia used were also effective and practical in every aspect of assessment. Students gave good responses towards HOTS abilities that could be developed during learning, including the ability to analyze, evaluate, and create. Therefore, online interactive multimedia oriented to HOTS through e-learning can be applied in physics lesson.
\end{abstract}

Keywords: E-learning; HOTS; Online Interactive Multimedia; Response

\section{Introduction}

Generally, Physics material is abstract and difficult to describe directly. Teaching conventional physics concepts is mostly done through explanation. This kind of teaching process does not give a deep understanding to students because they are not directly involved in learning (Huang \& Gramoll, 2004). Learning media plays an important role in learning activities because it facilitates educators to deliver learning materials to students (Asnadi, Ratminingsih, \& Myartawan, 2018; Damopolii \& Rahman, 2019; Sahara, Irwansyah, Darmalaksana, \& Ramdhani, 2018). The learning process that utilizes the media in its delivery will absolutely encourage more innovation related to teaching methods that can increase students' motivation and learning outcomes (Muryani, Sarwono, \& Nugraha, 2017). Learning will be more effective if students are given more opportunities to learn and discover a concept by themselves (Masruroh \& Prasetyo, 2018). One of the media use in learning that encourages the activeness of students to learn is through the use of technology in the form of computer media.

Current technological advances provide opportunities for educators to utilize computer media in learning (Wahyuni \& Zainnuri, 2017). There are many various computer learning media that available nowadays. On the other hand, there are also some available computer media that are less effective and can cause misconceptions for students. The results showed that there are a variety of computer media such as animation programs that are not in accordance to the concept of the lesson. For example in the physics material about motion, particularly in the motion animation about roller coasters. It has been observed that when it passed through the circuit, the speed is fixed. Whereas, according to the concept of

\footnotetext{
* Corresponding author.

Received 8 June 2019; Accepted 23 March 2020; Available online 31 March 2020 (c) 2020 JPI. All Rights Reserved
} 
mechanics, the speed should increase when it is moving down until it reaches the maximum speed. Meanwhile, when it is at a lowest point, it becomes slower when moving upward until it reaches a minimum speed at the top (Kristiyanto, 2016). Therefore, lecturers need to be selective in choosing learning media in order to make the students can understand the concept well without causing any misconceptions. Lecturers can modify computer learning media that are freely available on the internet by adding various material contents in accordance to the expected learning objectives.

One of the computer media use in learning that can be created by educators is interactive multimedia. Compare to ordinary multimedia, students can directly interact through interactive multimedia (Munir, Sutarno, \& Aisyah, 2018). Interactive multimedia integrates a variety of content such as text, animation, simulation, and virtual experiments that can be run interactively by utilizing computer media (Lindner, Eitel, Barenthien, \& Köller, 2018). Moreover, interactive multimedia allows students to actively interact and control the presented content by themselves (Fui-Theng Leow \& Mai Neo, 2014). Interactive multimedia also can change the students' learning habits who are initially passive to active (Hakim, Liliasari, Setiawan, \& Amir, 2019; Putra, Syamsyui, \& Radzuan, 2015). At last, interactive multimedia allows for feedback and makes students actively involved in learning.

The results showed that interactive multimedia was more effective in improving students' performance and good perceptions of the subjects given (Cheng, Basu, \& Goebel, 2009). Interactive multimedia also provides content that is more representative and easily understood by students (Savov, Antonova, \& Spassov, 2019). Presentation of interactive multimedia content cannot be obtained through conventional learning. Interactive multimedia presentations can also be in the form of video displays, animations, simulations. Even the presentation of evaluations can be presented in the form of practice questions, multiple choice and interactive essays that allow students to directly know the results of their performance after answering the questions given (Fui-Theng Leow \& Mai Neo, 2014). Interactive multimedia that has been developed can also simulate abstract material, so it can facilitate students in understanding the learning material.

A rapid development of internet technology nowadays provides opportunities for educators to use it as an innovative online learning media (Naidu, Bhat, \& Singh, 2019). The availability of learning resources can be obtained and studied freely through online access anytime. Students' motivation can be grown through online learning that is not limited in space and time. It also can be done anytime and anywhere, and last almost forever. Integrating interactive multimedia with online media in the form of e-learning is an effective step to facilitate students in learning (Allen, 1998). Interactive multimedia designed online can make it easier for students to learn independently so that their thinking skills can be trained by themselves. The complete content of the interactive multimedia is expected to be able to facilitate students in developing their thinking skills. Students' ability in thinking needs to be developed especially as a provision for them to face the real world. It can be done by providing adequate learning facilities, not only in the classroom but also outside.

The results of observations so far, especially for students of Physics Education Department, Faculty of Teacher Training and Education, Universitas of Papua found that students still have difficulty in understanding physical concepts, particularly the abstract ones such as electricity and magnetism. It maybe caused by the abstract material is difficult to describe directly (Yusuf \& Subaer, 2013). In addition, the limited facility that support the implementation of learning, especially those related to practicum, is one of the obstacles. The provision of practicum facilities, especially those related to abstract physical materials such as magnetic electricity, modern physics, and solid physics requires a relatively high cost. Of course, not all universities have adequate practicum equipment especially universities in eastern Indonesia, specifically at the Universitas Papua. Learning media that are available are KIT and simple teaching aids that are designed from simple materials. The media can only be used on certain materials, but not the abstract ones. Computer media also often be used but only limited to the presentation of material through a slide projector. Therefore, the delivery of material is only from lecturers to students. The use of computer learning media that is freely available on the internet also needs to be further developed such 
as the suitability of learning material, simplicity, and content of the material outlined. There are many computer media which precisely cause misconceptions for students. So, lecturers need to be selective in providing learning resources for students (Kristiyanto, 2016). A good computer media is the one that can provide clarity of learning material through animation, simulation, and interactive multimedia. Students need to be provided with effective learning resources, one of them is interactive multimedia. Interactive multimedia can simulate various kinds of physics concepts that can make it easier for students to understand the material. Students can simulate various physical quantities, display abstract material animations, and take measurements directly.

The development of computer learning media at this time is only focused on developing media content directly without paying attention to the presentation of the material. Most existing learning media are only presented offline or can only be accessed while learning in class (Tsay, Kofinas, \& Luo, 2018). It makes the students still experience difficulties in exploring their abilities due to limited access to learning media (Rajendra, M \& Sudana, M, 2018). In fact, there are still many available learning media nowadays that do not pay attention to the realm of students' abilities and the content of the problems presented does not require students' thinking skill. Therefore, teachers need to prepare the learning media by including various problems that can foster their thinking skill and can be freely accessed, so that they can learn not only in the classroom or in the laboratory but also outside the classroom.

Interactive multimedia allows to be integrated online through e-learning so that it can be accessed whenever and wherever the students are (Alsadhan, Alhomod, \& Shafi, 2014; Yusuf \& Widyaningsih, 2020). Students can develop their abilities through the use of online interactive multimedia through e-learning. Students do not only learn directly face to face, but can also learn whenever and wherever they are. The availability of interactive multimedia through e-learning is one effective solution to explain abstract physics material and make it easier for students to access it. Through learning media, it is expected to be able to develop students' thinking skills.

Nowadays, Universitas Papua has an e-learning portal. The portal was developed using Moodle Learning Management System (LMS). The e-learning enables the implementation of online learning. Various learning resources can be integrated through elearning such as hypertext and hypermedia, as well as learning evaluation facilities and online discussion forums. Although e-learning facilities have been provided, only a few lecturers use them as learning media. Its use is only limited for uploading material and assignments for students to be collected online. By referring to the results of the initial observations made in academic year 2018/2019, it was found that from 763 lecturers, there were only 15 lecturers (2\%) who used e-learning as learning media. Lecturers who use elearning are also mostly dominated from faculty of engineering, especially majoring in informatics engineering. Meanwhile, Universitas Papua has 14 faculties consisting of 54 study programs. The low utilization of e-learning is mostly due to the lack of lecturers' understanding in utilizing e-learning as a learning source. Therefore, researcher will optimize the use of e-learning by integrating various learning resources, one of them is interactive multimedia that can be accessed online by students. The interactive multimedia provide various content dealing with HOTS problems, so it is expected that students' thinking skills can be developed.

Students' thinking skills can be formed through the assistance of online interactive multimedia. The multimedia content is specifically designed covering various problems involving the ability to analyze, evaluate and create. The ability to think is very important in teaching and learning process, especially in universities. The ability to think is a cognitive ability that aims to gain knowledge (Istiyono, 2018). The ability to think that is expected to be mastered by students is the ability to think at a higher level or known as Higher Order Thinking Skills (HOTS). HOTS is the highest ability in the cognitive realm in accordance with Bloom's taxonomy.

HOTS is very important for students so that they can solve various problems, especially if they have entered the work environment. The low ability of students' HOTS is commonly 
influenced by various factors, such as the availability of effective learning media that presents HOTS problems (Yusuf \& Widyaningsih, 2019). Interactive multimedia that is designed consists of various HOTS problems, so students can develop their HOTS. Interactive multimedia is available online through e-learning, so that it can be accessed anytime. The use of online interactive multimedia oriented to HOTS using e-learning, is expected to be able to facilitate students in learning and developing their HOTS, such as the ability to solve various problems encountered.

\section{Methods}

This research is a type of development research. The development model used follows the ADDIE model which consists of some stages namely 1) Analysis, 2) Design, 3) Development, 4) Implementation, and 5) Evaluation (Aldoobie, 2015).

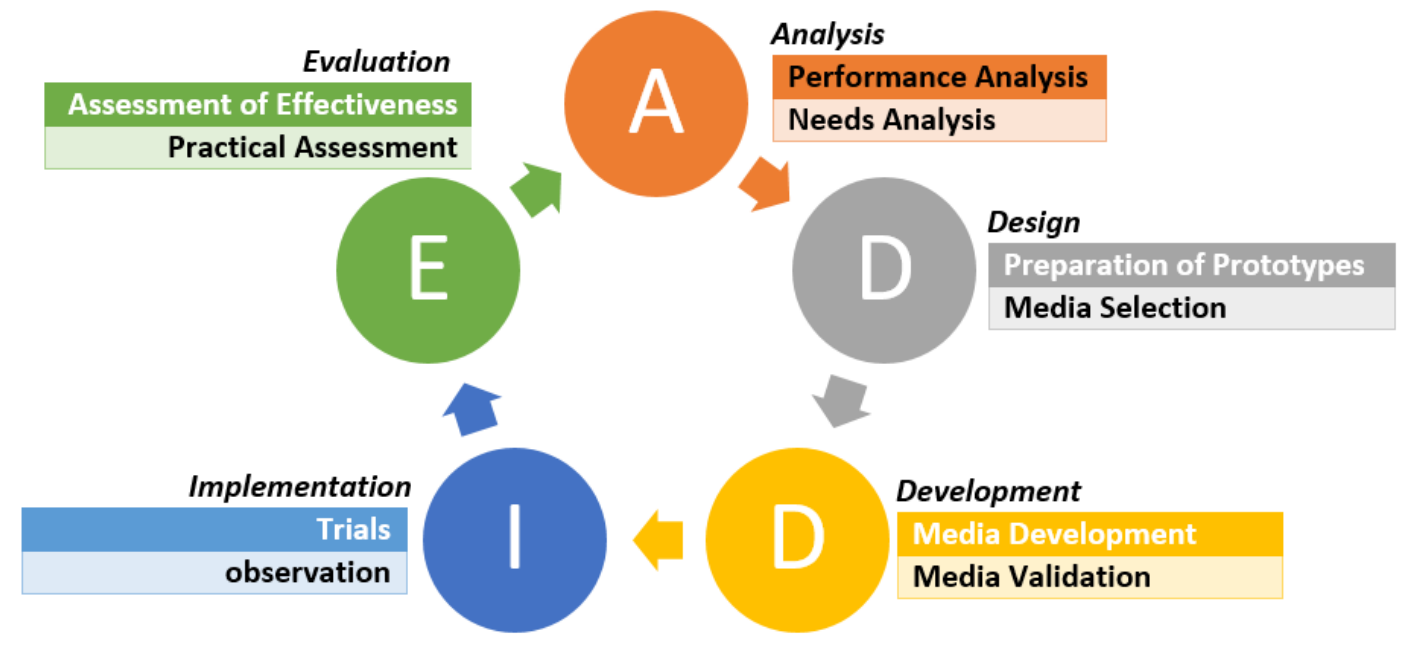

Figure 1. The Scheme of ADDIE Model.

In the analysis phase, needs and performance analysis are included to make a review towards the curriculum that going to be learned during the learning activities. In this activity, the researcher did an analysis about the material that was going to be presented which deals with electrical circuit especially the electric battery, current strength, resistor resistance, electrical power, resistor and capacitor circuit, Electrical Motion Force, Kirchoff's Law, and RC circuits. In this analysis activity, the researcher also carried out an analysis of students' initial abilities and available resources to support the implementation of learning using online interactive multimedia.

In the design phase, the preparation of prototype and media selection was used for the development of online interactive multimedia. At this stage, the researcher designed storyboard that consists of various items and content that will be displayed on online interactive multimedia. The media used in this interactive multimedia design was e-learning media using Moodle Learning Management System (LMS). E-learning using Moodle LMS provides various facilities such as assignment submission facilities, discussion forums, archives download, rankings, chat, online calendars, news, online quizzes, wikis, and external tools that allow students to access the other online learning resources (Alier, Guerrero, Gonzalez, \& Penalvo, 2010; Costa, Alvelos, \& Teixeira, 2012; Tee, Siti, Tengku, \& Zainudin, 2013). The content contained in interactive multimedia is designed using various softwares including Camtasia software to create video tutorials, Adobe Flash to develop animations and simulations, also Adobe Photoshop to develop images and various contents in interactive multimedia. Besides it could be designed independently, the content contained in this multimedia was also obtained from various online sources.

At the development stage, the development of online interactive multimedia was carried out in accordance with the designed storyboard. At this stage, the validation test was also 
carried out by involving media expert lecturers and physics course experts from Universitas Negeri Yogyakarta and practitioner lecturers from the Universitas Papua. Validation aims to obtain input and improvement of interactive multimedia that has been developed. Improvements to the interactive multimedia product are based on written suggestions and direct comments during discussions with the validators. The aspects of online interactive multimedia validation statement through e-learning consist of aspect of layout, content, navigation and function (C. Lee \& Cherner, 2015; Najjar, 1996; Walker \& Hess, 1984). The validation test used the Aiken $V$ formulation as formulated in equation (1) (Aiken, 1980, 1985).

$$
\mathrm{V}=\frac{\sum \mathrm{s}}{\mathrm{n}(\mathrm{c}-1)}
$$

$V$ is the validator agreement index regarding item validity, $s$ is the validator score minus the lowest score, $\mathrm{n}$ is the number of validator, and $\mathrm{c}$ is the number of categories that can be chosen by the validators (Kowsalya, Venkat Lakshmi, \& Suresh, 2012).

The next stage is the implementation phase. At this stage, a trial was carried out by online interactive multimedia in learning process. The test subjects in this study were 13 students of Physics Education Department in Universitas Papua who took basic physics courses in the even semester of academic year 2018-2019.

In the evaluation stage, an assessment was made regarding to the effectivity and practicality of the learning media. Assessment was carried out by students through filling out an online questionnaire provided through e-learning. Questionnaire aspects and statements are shown in Table 1 (J. Lee \& Martin, 2017). In Table 1, there are items of negative statements in each aspect of assessment namely item number 3 (R3-) dealing with aspects of effectivity and item number $1(\mathrm{R} 1+)$ dealing with aspects of practicality. The purpose of these negative items is to make the students read the statements and choosing the most suitable answers from the options given. The analysis of questionnaire for effectivity and practicality responses were using Rasch modeling technique. Rasch modeling is done with the assistance of Ministep application. Rasch modeling produced the most accurate analysis results and was currently unbeatable compare with other analytical techniques (Alagumalai, Curtis, \& Hungi, 2005).

Table 1. Aspects and Statements of Students' Response Toward Online Interactive Multimedia Through E-learning

\begin{tabular}{ccl}
\hline Aspects & Item Numbers & \multicolumn{1}{c}{ Statement Items } \\
\hline Effectivity & R1+ & a. The use of interactive multimedia increases the learning \\
enthusiasm
\end{tabular}




\section{Results and Discussions}

\subsection{The Display of Online Interactive Multimedia oriented to HOTS using E-Learning on the}

Physics Material about Electrical Circuit

Online interactive multimedia that has been developed consisted of two main parts, namely interactive material presentation and HOTS exercises. This interactive multimedia consists of the presentation of electrical circuit in physics material through graphic media, sound, animation, interactive simulations, hypertext, and virtual laboratory facilities which were needed to solve HOTS-oriented problems. This interactive multimedia was displayed online using Moodle LMS, so students can access it anytime.

Moodle is an easy-to-use platform as an e-learning media. The interface is based on HTML 5 and can be accessed on a computer or through any cellular phone (Yildiz, Tezer, \& Uzunboylu, 2018). The completeness of e-learning facilities by Moodle LMS can facilitate educators in presenting effective and various learning resources (Bi \& Shi, 2019; Costa et al., 2012; Widiana, 2016). At the beginning of learning, the use of various e-learning features should be explained to students. They initially experienced difficulties because they were not accustomed to use e-learning as a learning resource. The solution was that the lecturer had to provide a guidance about the use of e-learning and interactive multimedia in order to make the students be able to optimize it. Figure 2 showed the display of online interactive multimedia through e-learning using the Moodle LMS.

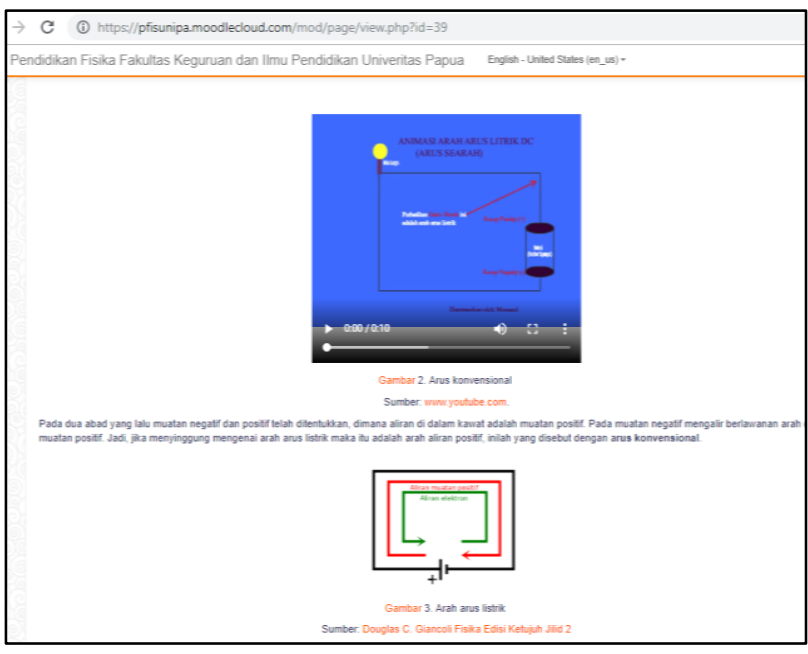

a

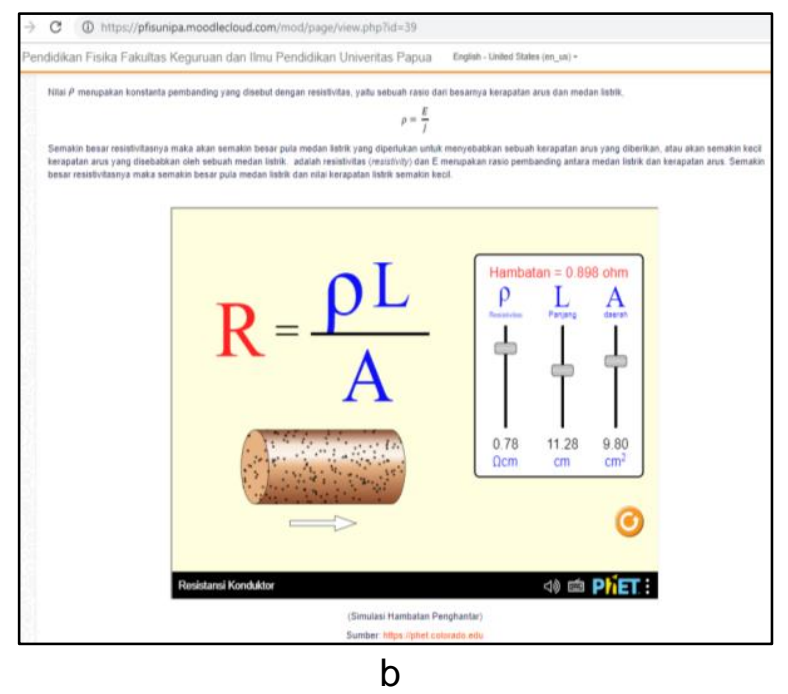

b

Figure 2. Some of the facilities available in online interactive multimedia using e-learning (a) presentation of material in the form of video tutorials and animations, (b) interactive simulation content.

The features in online interactive multimedia are hypertext, video tutorials, animations, and interactive simulations. Students could watch video tutorials related to the explanation of the physics material being studied. Through interactive simulations on this interactive multimedia, students could directly control changes in the value of physical quantities that occur and also see the changes. This interactive multimedia was also equipped with interactive evaluation questions. Students were able to know directly the correct problem solving after they answered the questions provided. In addition, hypertext provided in this interactive multimedia was connected with various learning resources that can be accessed online by students.

Video presentations in this interactive multimedia were obtained both from selfdesigned and Youtube (https://youtube.com). Interactive simulations were also found in this interactive multimedia. Not only it can be designed independently, interactive simulations were also obtained from various sources on the internet such as simulations from Physics Education Technology (PhET) which can be downloaded freely on the website https://phet.colorado.edu. This interactive multimedia was also designed by including content 
and questions that cover HOTS, namely aspects of analyzing, evaluating, and creating. Students could develop their HOTS through the presentation of HOTS problems and questions in interactive multimedia.

\subsection{Validity of Online Interactive Multimedia oriented to HOTS}

The results of the validators assessment which consisted of media validator expert, material expert as well as the practitioner validator are shown in Table 2 . The assessment results indicated that all statements were approved by the validators. V Aiken calculation results on each statement obtained a greater value than the value of the table which is 0.75 (for 7 validators with a choice of 4 Likert scales).

The validators assessment results generally indicate that online interactive multimedia oriented to HOTS using e-learning, obtained valid results in every aspect, namely layout aspect, content aspect, navigation aspect, and function aspect. This showed that online interactive multimedia oriented to HOTS using e-learning that have been developed was worth testing in limited classes.

Table 2. Results of Validator Assessments Based on The Aspects and Statements of The Instrument

\begin{tabular}{|c|c|c|c|}
\hline \multirow{5}{*}{$\begin{array}{l}\text { No. } \\
1 .\end{array}$} & Aspects and Statements & V Aiken & Criteria \\
\hline & Layout Aspects & & \\
\hline & a. Content layout in interactive multimedia is proportional & 0,76 & Valid \\
\hline & b. The display of interactive multimedia attracts attention & 0,95 & Valid \\
\hline & c. The compatibility of background with the content usage & 0,76 & Valid \\
\hline \multirow[t]{5}{*}{2.} & Content Aspects & & \\
\hline & a. The suitability of content with learning objectives & 0,90 & Valid \\
\hline & b. The material description is presented in full & 1,00 & Valid \\
\hline & $\begin{array}{l}\text { c. Physics material in interactive multimedia is in accordance with } \\
\text { the development of science (actual) }\end{array}$ & 0,90 & Valid \\
\hline & $\begin{array}{l}\text { d. There are illustrations / examples that can ease to understand } \\
\text { the material }\end{array}$ & 0,90 & Valid \\
\hline \multirow[t]{5}{*}{2.} & Navigation Aspects & & \\
\hline & a. Directories and categories are clear to users & 0,90 & Valid \\
\hline & b. Use of simple / consistent content in each display & 0,76 & Valid \\
\hline & c. The use of content in interactive multimedia can be read clearly & 0,95 & Valid \\
\hline & d. Automation features in interactive multimedia & 0,90 & Valid \\
\hline \multirow[t]{4}{*}{3.} & Functional Aspects & & \\
\hline & a. Interactive multimedia is easy to use (user friendly) & 0,81 & Valid \\
\hline & b. Resources can be accessed / functioned properly & 0,81 & Valid \\
\hline & c. Interactive multimedia can develop HOTS & 0,90 & Valid \\
\hline
\end{tabular}

Table 2 showed the valid results on each statement. However, in the suggestion and comment section, there were also a variety of suggestions from the validators that were related to the consistency of content display size of interactive multimedia that needs to be adjusted if it is used in different devices. Display includes a variety of content such as video tutorials, animations and simulations that must be displayed proportionally according to the screen size of the device used (Putra et al., 2015). Content display of interactive multimedia needs to be designed proportionally and in accordance with the resolution of the device used. The display settings of interactive multimedia become very important in making the students feel comfortable while accessing and runs it well using computer desktop or tablet.

\subsection{Effectiveness of Online Interactive Multimedia Oriented to HOTS}

The final stage in the development of online interactive multimedia through e-learning is the evaluation stage. An evaluation needed to be done to ensure that the product being developed is functioning as it should. Evaluation can be done through test and non-test instruments (Alsadhan et al., 2014). In this study, a non-test evaluation was conducted using a questionnaire about students' responses to the use of online interactive multimedia using 
e-learning. The result of students' response after learning process can be categorized based on the statement of effectivity and practicality of interactive multimedia that has been developed. The effectivity of interactive multimedia is related to the function of interactive multimedia in accordance with the expected learning objectives (Sarimanah, 2016). Evaluation of students' responses to the effectivity and practicality of interactive multimedia was analyzed using Rasch model. The results of students' response analysis related to the effectivity assessment of interactive multimedia is shown in Figure 3.

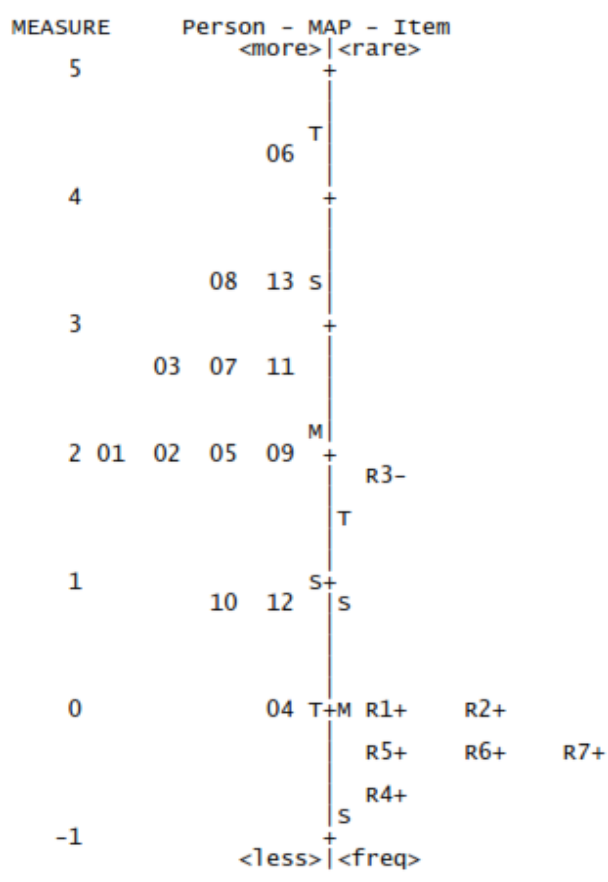

Figure 3. Students response to the effectivity of using online interactive multimedia using e-learning.

Figure 3 showed the students' response assessment related to the statement of the effectivity of using interactive multimedia. The measurement shows that the value of person measure +2.20 greater than 0.00 logit which indicates that students agree on the effectivity of using online interactive multimedia in learning. In Figure 3, the left side shows the distribution of person or respondent position, while on the right side shows the position of the item or statement. The average value of logit person was higher than the average value of logit item. It indicates that the respondent were agree easily with the statements given. The distribution of person positions showed that there were 10 students $(06,08,13,03,07,11$, $01,02,05$, and 09 ) of the 13 students who answer the "strongly agree" in the statements of effectivity questionnaire.

The statement that had the greatest logit value or was difficult to agree compared to the others is the statement R3-. That statement was one form of negative statements about interactive multimedia cultivate less curiosity. Negative statements are provided in order to make students as respondents be more careful and systematic in filling out the questionnaire. However, it is also necessary to add interactive multimedia content related to some aspects by raising a variety of initial problems related to daily life to foster students' curiosity. Students need to be given problems related to daily life in learning, so that their curiosity can be trained to come up with various creative ideas (Widyaningsih \& Yusuf, 2019).

The most easily agreed statement compared to the others is the R4 + statement about interactive multimedia can create an atmosphere of independent learning. Students can learn independently through the use of interactive multimedia that is provided online through elearning (Huang \& Gramoll, 2004). Students can access various learning resources through 
the use of online interactive multimedia anytime (Muller, Lee, \& Sharma, 2008). Students can develop their own abilities and interact with each other between lecturers and students as well as among students through discussion forums that are available online (Hamar, Funato, Ogasawara, Dranga, \& Tse, 2005; Yusuf, Widyaningsih, \& Sebayang, 2018). The use of online interactive multimedia also can develop students 'HOTS even more effective because they are equipped with various issues that demand students' thinking abilities.

\subsection{Practicality of Online Interactive Multimedia oriented to HOTS}

The assessment of students response related to practicality includes the statements about the ease of using interactive multimedia as a support for learning activities. Learning devices that meet practical criteria show that they are interesting and easy to use (Yusuf \& Subaer, 2013). Practicality of interactive multimedia is shown in Figure 4.

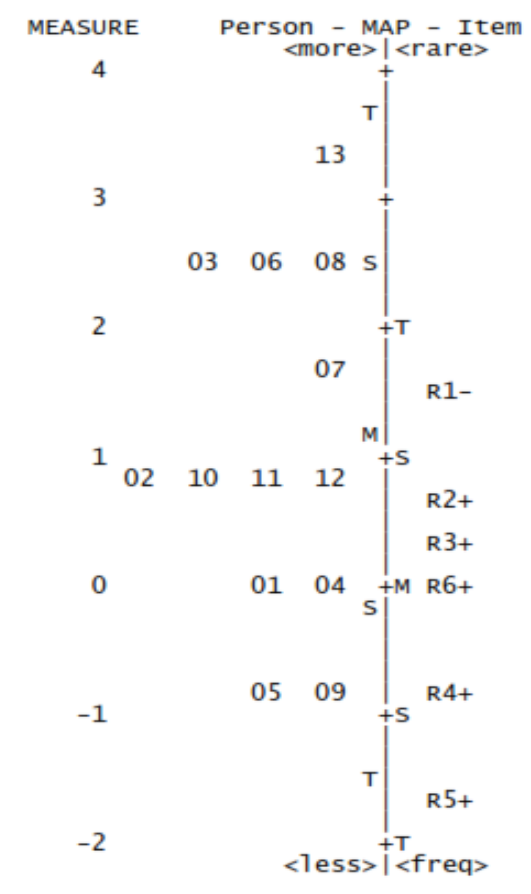

Figure 4. Students' Response to The Practicality of Using Online Interactive Multimedia Through E-Learning

Practicality measurement results showed that the value of person measure is +1.11 (greater than 0.00 ) which indicates that students agree on the practicality of using interactive multimedia in learning. Figure 4 shows that there were 5 students $(13,03,06,08$, and 07$)$ who agreed to all items of the statement given. Other student values are distributed according to their level of agreement towards the statement items given.

The statement that is most easily agreed by students is the statement of R5 + and R4 + . Those statements relate to the material about interactive multimedia presented sequentially / coherently and the presentation of images, illustrations, graphics, videos, animations, or simulations in interactive multimedia attracts attention. Students are interested and easy to learn through online interactive multimedia on e-learning. Students can access various learning resources and develop their thinking skills, especially related to HOTS issues.

In general, students give a positive assessment towards the ease of using interactive multimedia in learning. Although at the beginning of learning, there were still technical obstacles such as students who could not access e-learning because they forgot their username and password. Moreover, students also initially did not understand well some of the features of e-learning and their low participation in online discussion forums. Various improvements have been made such as the provision of user manuals, assuming that 
students are present in learning if they access learning resources in e-learning, and assessments for students who are active in the discussion forums. Based on these improvements, students would become enthusiastic to the learning and could use e-learning and interactive multimedia as well. Students were also able to develop their thinking abilities to be creative in analyzing, evaluating, and creating various physics concepts that have been learned. The use of interactive multimedia was enjoyed by students because they were challenged to solve various HOTS problems.

\subsection{Implications of Interactive Multimedia on Scientific Development}

The implications of this interactive multimedia on the development of science today is the availability of learning resources, especially those related to HOTS issues that are very important for students. HOTS is very important, especially for students, so that they can solve each problem correctly and accurately (Istiyono, Dwandaru, \& Rahayu, 2018). The use of online interactive multimedia through e-learning is one of the right solutions as the application of technology in learning to improve the students' ability, especially HOTS. Measurement of students' abilities through the use of Computerized Adaptive Test (CAT) is more effective than paper-based tests (Istiyono, Dwandaru, Lede, Rahayu, \& Nadapdap, 2019). This shows that the use of technology in learning whether in the implementation or the evaluation is very important. Providing appropriate learning resources can help students develop their HOTS (Tanujaya, Mumu, \& Margono, 2017). The results showed that students' HOTS became better through learning by utilizing e-learning compared to conventional learning or face-to-face meeting in the classroom (Yaniawati, 2013). Online interactive multimedia through e-learning gives the simplicity for students to learn and develop their HOTS. E-learning also provides a forum for discussion and chat, so that students can interact directly with other students and lecturers (de Freitas \& Oliver, 2005). Learning through e-learning allows students to access various learning resources, so that they can easily understand the learning materials (Tan \& Halili, 2015). Students' HOTS can be developed through the presents of effective teaching materials which covering HOTS content and problems.

Another implication is the availability of learning media to explain abstract physics material that is difficult to describe directly. This interactive multimedia provides an opportunity for students to control and simulate various abstract physical quantities that are related to electrical circuit material. Students can create physical concepts about electrical circuits. Students can also conduct experiments virtually like in a real laboratory. Interactive multimedia is an effective media to explain phenomena that cannot be observed directly (Mahmudah, Munzil, \& Yulianti, 2018). Interactive multimedia can display abstract learning materials in the form of visual, animation, or graphic that will make it easier for students to understand the lesson (Cheng et al., 2009; Huang \& Gramoll, 2004). Completeness of the facilities presented in this interactive multimedia provides opportunities for students to learn independently and develop their thinking skills. They also can understand the subject matter properly. Interactive multimedia can also develop aspects of students' knowledge and skills because they are directly involved in learning (Rajendra, M \& Sudana, M, 2018). The analysis of students' responses contained the effectivity and practicality of the developed media showed the strongly agree results towards the use of interactive multimedia in learning. Evaluation of students' responses to the use of interactive multimedia was 81.10 or it is in the excellent category which indicates that students like to learn through interactive multimedia (Fatimah, Yusuf, \& Bancong, 2014). Student learning outcomes between those who use interactive multimedia and those who do not use interactive multimedia in learning showed that the $p$-value is 0.00 or smaller than $p$-sig. 0.05 . It indicated that there were significant differences, as well as their response to the lesson that students were more interested in learning by using interactive multimedia (Rajendra, M \& Sudana, M, 2018). Difference between HOTS of students before and after applying interactive multimedia using PheT media was obtained significance value $0.00<0.05$. The results of the study also showed that HOTS of students became higher after the implementation of PheT interactive multimedia in learning (Yusuf \& Widyaningsih, 2019). The use of interactive multimedia 
especially online presentation made it easy for students to access and develop their learning abilities. The results of student assessments in general showed that interactive multimedia is practical and effective to be used in order to develop HOTS.

Compared to learning media that are available on the internet, this interactive multimedia should be associated with various HOTS problems in real life, so students are challenged in learning. Although at the beginning of learning, students still have difficulty in recognizing e-learning features, but in the end they can optimize the various facilities available. Students also respond well to the lessons, they enjoy learning process and can understand the material well. The availability of interactive multimedia is currently difficult to find, especially those who speak with content and problems to develop students' HOTS (Huang \& Gramoll, 2004; Yusuf \& Widyaningsih, 2019). Computer learning media should be a compilation of study results related to various real-life problems involving thinking skills and problem solving (Tchounikine, 2011). The use of technology in effective learning can be applied if students can comfortably learn and be able to develop their abilities and understanding the material being studied (Asnadi et al., 2018). This interactive multimedia is also available online through e-learning so students can learn whenever and wherever they are. Although the results of the development of online interactive multimedia showed good results on each assessment, which is valid according to the validators, effective and practical according to the students, but there are still some constraints in the application of learning using interactive multimedia. Constraints faced include the lack of direct physical interaction and face to face in class (Alsadhan et al., 2014). This became a problem for almost all online learning. However, indirect interaction can still be established through communication created in online discussion forums, chat facilities, and video conferencing facilities that enable online real-time face-to-face among e-learning users. Another constraint faced in this development is that lecturers need to spend more time in designing and compiling online interactive multimedia, so it requires considerable effort and cost.

\section{Conclusions and Suggestions}

Online interactive multimedia oriented to HOTS through e-learning is a product of the development of a valid, effective, and practical use in physics learning. The results of the validation assessment by experts and practitioner validators obtained valid results on each aspect of the statement, namely the aspects of layout, content, navigation and function. The development of online interactive multimedia oriented to HOTS can develop students' HOTS capabilities. Students give a good response assessment towards the effectivity and practicality of online interactive multimedia oriented to HOTS in learning physics. They enjoy learning by utilizing interactive multimedia. Students can develop their HOTS abilities including the ability to analyze, evaluate and create. Online interactive multimedia that has been designed allows students to learn whenever and wherever they are. Lecturers can also control the development of each student through e-learning that is integrated with online interactive multimedia.

\section{Acknowledgments}

We would like to thank the Ministry of Research, Technology, and Higher Education for the Grant Research Cooperation between Colleges Universitas Papua and Universitas Negeri Yogyakarta (Contract Number: 198/SP2H/AMD/LT/DRPM/2020) for funding assistance so that this research can be done well.

\section{References}

Aiken, L. R. (1980). Content Validity and Reliability of Single Items or Questionnaires. Educational and Psychological Measurement, 40(4), 955-959.

Aiken, L. R. (1985). Three Coefficients for Analyzing the Reliability and Validity of Ratings. Educational and Psychological Measurement, 45(1), 131-142.

Alagumalai, S., Curtis, D. D., \& Hungi, N. (2005). Applied Rasch Measurement: a Book of Exemplars Education in the Asia-Pacific Region : Issues, Concerns and Prospects. 
Aldoobie, N. (2015). ADDIE Model. American International Journal of Contemporary Research, 5(6), 72.

Alier, M. F., Guerrero, M. J. C., Gonzalez, M. A. C., \& Penalvo, F. J. G. (2010). Interoperability for LMS: the missing piece to become the common place for e-learning innovation. International Journal of Knowledge and Learning, 6(2-3), 130-141.

Allen, R. (1998). The Web: interactive and multimedia education. Computer Networks and ISDN Systems, 30(16), 1717-1727.

Alsadhan, A. O., Alhomod, S., \& Shafi, M. M. (2014). Multimedia Based E-learning: Design and Integration of Multimedia Content in E-learning. IJET, 9(3), 26-30.

Asnadi, I. W. S. W., Ratminingsih, N. M., \& Myartawan, I. P. N. W. (2018). Primary Teachers' and Students' Perception on the Use of ICT-Based Interactive Game in English Language Teaching. Jurnal Pendidikan Indonesia, 7(1), 10-20.

Bi, X., \& Shi, X. (2019). On the Effects of Computer-assisted Teaching on Learning Results Based on Blended Learning Method. International Journal of Emerging Technologies in Learning (IJET), 14(01), 58.

Cheng, I., Basu, A., \& Goebel, R. (2009). Interactive multimedia for adaptive online education. IEEE Multimedia, 16(1), 16-24.

Costa, C., Alvelos, H., \& Teixeira, L. (2012). The Use of Moodle e-learning Platform: A Study in a Portuguese University. Procedia Technology, 5, 334-343.

Damopolii, I., \& Rahman, S. R. (2019). The effect of STAD learning model and science comics on cognitive students achievement. In Journal of Physics: Conference Series (Vol. 1157, p. 22008). IOP Publishing.

de Freitas, S., \& Oliver, M. (2005). Does E-learning Policy Drive Change in Higher Education?: A case study relating models of organisational change to e-learning implementation. Journal of Higher Education Policy and Management, 27(1), 81-96.

Fatimah, Yusuf, I., \& Bancong, H. (2014). Implementasi Pembelajaran Kurikulum 2013 berbasis Multimedia Interaktif pada Pokok Bahasan Listrik Magnet terhadap Aktivitas, Persepsi, dan Hasil Belajar Peserta Didik di SMA Tut Wuri Handayani Makassar. Jurnal Fisika Indonesia, 53(XVIII), 62-65.

Fui-Theng Leow, \& Mai Neo. (2014). Interactive Multimedia Learning: Innovating Classroom Education in a Malaysian University. Turkish Online Journal of Educational Technology, 13(2), 99-110.

Hakim, A., Liliasari, L., Setiawan, A., \& Amir, M. (2019). Thermodynamics interactive multimedia to improve physics prospective teacher's generic science skills. Journal of Physics: Conference Series, 1157(032026), 1-5.

Hamar, J., Funato, H., Ogasawara, S., Dranga, O., \& Tse, C. K. (2005). Multimedia based elearning tools for dynamic modeling of DC-DC converters. In 2005 IEEE International Conference on Industrial Technology (pp. 17-22).

Huang, M., \& Gramoll, K. (2004). Online interactive multimedia for engineering thermodynamics. In ASEE Annual Conference Proceedings (pp. 10661-10671).

Istiyono, E. (2018). IT-based HOTS assessment on physics st learning as the 21 century demand at senior high schools: Expectation and reality IT-Based HOTS Assessment on Physics Learning as the 21 st Century Demand at Senior High Schools: Expectation and Reality. AIP Conference Proceedings, 2014(020014), 1-6.

Istiyono, E., Dwandaru, W. S. B., Lede, Y. A., Rahayu, F., \& Nadapdap, A. (2019). Developing IRT-Based Physics Critical Thinking Skill Test: A CAT to Answer 21st Century Challenge. International Journal of Instruction, 12(4), 267-280.

Istiyono, E., Dwandaru, W. S. B., \& Rahayu, F. (2018). Pengembangan Tes Creative Thinking Skills Fisika SMA (PhysCreTHoTS) berdasarkan Teori Tes Modern. Cakrawala Pendidikan, XXXVII(2), 190-200.

Kowsalya, D. N., Venkat Lakshmi, H., \& Suresh, K. P. (2012). Development and Validation of a Scale to assess Self-Concept in Mild Intellectually Disabled Children. International Journal of Social Sciences \& Education, 2(4).

Kristiyanto, W. H. (2016). Sebuah Kritik: Animasi Fisika yang Tidak Sesuai Fisika. Berkala Fisika Indonesia, 8(2), 49-56. 
Lee, C., \& Cherner, T. S. (2015). A Comprehensive Evaluation Rubric for Assessing Instructional Apps. Journal of Information Technology Education: Research, 14(May), 21-53.

Lee, J., \& Martin, L. (2017). Investigating students' perceptions of motivating factors of online class discussions. International Review of Research in Open and Distance Learning, 18(5), 148-172.

Lindner, M. A., Eitel, A., Barenthien, J., \& Köller, O. (2018). An integrative study on learning and testing with multimedia: Effects on students' performance and metacognition. Learning and Instruction, 01(002), 1-9.

Mahmudah, M., Munzil, M., \& Yulianti, E. (2018). Validity and Reliability Study of ScienceEdutainment Interactive Multimedia on Earth Topic for the 7th Graders of Junior High Schools. Jurnal Penelitian Fisika Dan Aplikasinya (JPFA), 8(1), 42.

Masruroh, A. N., \& Prasetyo, Z. K. (2018). Effect of E-Module with Guided Inquiry Approach Containing Nature of Science to Student's Science Literacy. E-Journal Pend. IPA, 7(3), $165-171$.

Muller, D. A., Lee, K. J., \& Sharma, M. D. (2008). Coherence or interest: Which is most important in online multimedia learning? Australasian Journal of Educational Technology, 24(2), 211-221.

Munir, Sutarno, H., \& Aisyah, N. S. (2018). The development of interactive multimedia based on auditory, intellectually, repetition in repetition algorithm learning to increase learning outcome. Journal of Physics: Conference Series, 1013(1), 1-9.

Muryani, C., Sarwono, \& Nugraha, S. (2017). Importance Developing E-Learning for High School Students In Sragen Regency, Central Java. International Journal of Pedagogy and Teacher Education (IJPTE), 1(2), 139-146.

Naidu, V. R., Bhat, A. Z., \& Singh, B. (2019). Cloud Concept for Implementing Multimedia Based Learning in Higher Education. In A. Al-Masri \& K. Curran (Eds.), Smart Technologies and Innovation for a Sustainable Future (pp. 81-84). Cham: Springer International Publishing.

Najjar, L. J. (1996). Multimedia Information and Learning. Educational Multimedia and Hypermedia, 5(2), 129-150.

Putra, A., Syamsyui, E., \& Radzuan, N. F. M. (2015). Development of Multimedia Interactive Module for Learning Adobe Photoshop CS4. Scientific Journal of Ppi-Ukm, 2(1), 38-42.

Rajendra, M, I., \& Sudana, M, I. (2018). The Influence of Interactive Multimedia Technology to Enhance Achievement Students on Practice Skills in Mechanical Technology. Journal of Physics: Conference Series, 953(012104), 1-5.

Sahara, R., Irwansyah, F. S., Darmalaksana, W., \& Ramdhani, M. A. (2018). Utilization of Social Media Vlog to Enhance Creativity Students in Project Based Learning, 260(Icomacs), 68-71.

Sarimanah, E. (2016). Efeectivenes of PQ4R Metacognitive Strategy Based Reading Learning Models in Junior High School. International Journal of Language Education and Culture Review, 2(1), 74-81.

Savov, S. A., Antonova, R., \& Spassov, K. (2019). Multimedia Applications in Education. In A. Al-Masri \& K. Curran (Eds.), Smart Technologies and Innovation for a Sustainable Future (pp. 263-271). Cham: Springer International Publishing.

Tan, S. Y., \& Halili, S. H. (2015). Effective Teaching of Higher-Order Thinking (HOT) in Education. The Online Journal of Distance Education and E-Learning, 3(2), 41-47.

Tanujaya, B., Mumu, J., \& Margono, G. (2017). The Relationship between Higher Order Thinking Skills and Academic Performance of Student in Mathematics Instruction. International Education Studies, 10(11), 78-85.

Tchounikine, P. (2011). Computer Science and Educational Software Design. London: Springer.

Tsay, C. H.-H., Kofinas, A., \& Luo, J. (2018). Enhancing student learning experience with technology-mediated gamification: An empirical study. Computers \& Education, 121, 117. 
Wahyuni, D. S., \& Zainnuri, H. (2017). Boostering Students' Life Skill through IT Based Project Learning. Advances in Social Science, Education and Humanities Research (ASSEHR), 158(Ictte), 319-328.

Walker, D. F., \& Hess, R. D. (1984). Evaluation in courseware development. Instructional Software: Principles and Perspectives for Design and Use, 204-215.

Widiana, I. W. (2016). E-Modul berorientasi Pemecahan Masalah dalam Pembelajaran Statistik Inferensial. In Seminar Nasional Hasil Penelitian dan Pengabdian Kepada Masyarakat (pp. 529-540). Denpasar, Bali: LPPM Unmas Denpasar.

Widyaningsih, S. W., \& Yusuf, I. (2019). Influence of RMS model (reading, mind mapping, and sharing) on student learning outcomes in school laboratory course. Journal of Physics: Conference Series, 1157(032024), 1-6.

Yaniawati, R. P. (2013). E-Learning to Improve Higher Order Thinking Skills (HOTS) of Students. Journal of Education and Learning (EduLearn), 7(2), 109-120. https://doi.org/10.11591/edulearn.v7i2.225

Yildiz, E. P., Tezer, M., \& Uzunboylu, H. (2018). Student Opinion Scale Related to Moodle LMS in an Online Learning Environment: Validity and Reliability Study. International Journal of Interactive Mobile Technologies (IJIM), 12(4), 97-108.

Yusuf, I., \& Subaer. (2013). Pengembangan perangkat pembelajaran fisika berbasis media laboratorium virtual pada materi dualisme gelombang partikel di SMA Tut Wuri Handayani Makassar. Jurnal Pend. IPA Indonesia, 2(2), 189-194.

Yusuf, I., \& Widyaningsih, S. W. (2019). HOTS profile of physics education students in STEM-based classes using PhET media. Journal of Physics: Conference Series, 1157(032021), 1-5.

Yusuf, I., \& Widyaningsih, S. W. (2020). Implementing E-Learning-Based Virtual Laboratory Media to Students ' Metacognitive Skills. International Journal of Emerging Technologies in Learning (IJET), 15(5), 63-74.

Yusuf, I., Widyaningsih, S. W., \& Sebayang, S. R. B. (2018). Implementation of E-learning based-STEM on Quantum Physics Subject to Student HOTS Ability. Turkish Science Education, 15(December), 67-75. 